\title{
The Battered Child Syndrome: Parents and Children as Objects of Medical Study
}

The roots of post-1960s concerns about child abuse lay in the 1940s and in particular in research conducted by paediatric radiologists in America and Britain. This chapter explores how such research named the 'battered child syndrome' and, in doing so, directed concern anew to physical violence against young infants. Clashes between and within medical professions shaped this dynamic transnational research context. In debates between radiology, paediatrics, ophthalmology, and dermatology, children and parents affected by abuse were primarily constituted as objects of study, and they were not directly engaged in discussion. Further, there was little analysis of the long-term effects of abuse.

Nonetheless, the roots of later influence for children and parents were visible in these early debates, and this chapter provides important framing for the post-1960s developments traced in this book, and for the rise of experiential and emotional forms of expertise. Notably, the NSPCC established an innovative new unit to research battered children, which also drew attention to the psychological characteristics of violent parents. Further, early clinical debates also expressed concerns about child wellbeing. While these studies and debates were framed in paternalist and heavily gendered terms, they also contributed to a moment in which new challenges were made to medical and social work expertise. By considering the inner lives of parents, and the effects of their emotions and experiences, clinicians and social workers began to discuss and reflect on their own

J. Crane, Child Protection in England, 1960-2000, Palgrave Studies in the History of Childhood, https://doi.org/10.1007/978-3-319-94718-1_2 
sources of authority, and on the utility — or failures - of professional detachment. By reflecting on children's interests, furthermore, professional conceptions of the child remained characterised by vulnerability but also moved towards asking how children could be empowered and made expert.

\section{The 'Battered Child Syndrome'}

\section{America}

To an extent, medical research drove the re-emergence of concerns around child protection in Britain and America in the post-war period. Descriptions of this time by historians and social policy theorists focus on the work of a series of pioneering male paediatric radiologists and the development of this profession. ${ }^{2}$ Significant, and publishing sporadically from the mid-1940s until the mid-1950s, were John Caffey, Frederic Silverman, Paul Woolley, and William Evans, each of whom conducted research which utilised x-ray data to understand - and to make visible - the injuries of physically abused children. ${ }^{3}$ These men were working at a time when radiology itself was relatively new, with $\mathrm{x}$-rays only discovered in 1895 and then patchily adopted throughout Britain and America as a profession developed through the 1920 s and 1930s, overcoming initial industrial injuries. ${ }^{4}$

The men's research began to draw attention to the idea that parents may have purposefully inflicted children's injuries, discussing parental violence for one of the first times in medical press. Caffey wrote that the fractures he observed 'appear to be of traumatic origin'. ${ }^{5}$ Silverman argued that parents may 'permit trauma and be unaware of it, may recognize trauma but forget or be reluctant to admit it, or may deliberately injure the child and deny it'. ${ }^{6}$ Woolley and Evans, conducting a retrospective study of children's hospital records, considered the 'aggressive, immature or emotionally ill' characters of certain parents and argued that medical assessment must pay attention. ${ }^{7}$ These assertions were relatively tentative and made years apart, but nonetheless significant in connecting physical injury to violence, and in pushing for social assessment to become a medical responsibility.

Building on this small but important and growing body of literature, the paediatrician C. Henry Kempe was the first to explicitly detail and examine child battering at length in medical press. $^{8}$ A Jewish immigrant from Germany to America in 1939, Kempe became the youngest chairman of the Paediatrics Department at the University of Colorado at the age of 34 in 
1956. In 1962, Kempe published an article, 'The Battered Child Syndrome', in the Journal of the American Medical Association; purposefully choosing the dramatic term 'battered child', he later commented, as a 'jazzy title, designed to get physicians' attention'. ${ }^{9}$ The article's co-authors were a professor of paediatrics, Henry Silver; a professor of psychiatry, Brandt Steele; an assistant resident in obstetrics and gynaecology, William Drogemueller; and Frederic Silverman, the paediatric radiologist mentioned earlier. The authors described the 'battered child syndrome' as a 'clinical condition in young children', usually under three though possibly of 'any age', who had been subject to serious physical violence. ${ }^{10}$ Emphasising that this was a 'frequent cause of permanent injury or death', the authors urged that physicians must consider this as a cause in children exhibiting symptoms such as fractures, soft tissue swellings, and skin bruising. ${ }^{11}$

The research of a small group drawn from paediatric radiology, paediatrics, psychiatry, obstetrics, and gynaecology was thus significant in bringing attention to an area that many clinicians had previously shied away from: violence against children, and in calling on physicians to assess parental explanations critically. This work relied heavily on the x-ray image. Discussing this, Kempe's initial article explained, 'To the informed physician, the bones tell a story the child is too young or too frightened to tell'. ${ }^{12}$ In this account, the 'informed physician' was highly significant in terms of interpreting the $\mathrm{x}$-ray image, but the image itself was also a key provider of data that had previously only been accessible by speaking to the child themselves. The $\mathrm{x}$-ray image was to make the invisible visible. In doing so, this image would bring new attention to the child's physical injuries. Yet, it would also distract attention from children's individual testimonies, potentially replacing, rather than bolstering, interest in child voice. The x-ray image often revealed that children's bones were healing, demonstrating that without this internal examination, any external evidence of the child's injury may have been lost.

Given the significance of the $x$-ray image itself in discussing the battered child syndrome in America, technicians and members of radiological laboratory teams were key in this moment, producing the images that radiologists later interpreted and disseminated through publications. One of the earliest authors on $\mathrm{x}$-rays and childhood violence-Caffeyacknowledged this while accepting an award in 1965, praising the 'faithful and skilful labors' of his laboratory team. In particular, Caffey accepted that his technician Edgar Watts and department supervisor Moira Shannon had saved him 'literally thousands of hours' with their work. ${ }^{13}$ The medical 
research in this area was thus published by a small group of individuals, but conducted by, and raising awareness amongst, a broader community of technicians, assistants, and research laboratory staff. This is significant to acknowledge, because it spoke to a context in which concern about child protection was not only constructed by, or meaningful to, prestigious male paediatricians and radiologists. Indeed, this point demonstrates that both new technologies and auxiliary professions played a key role in re-awakening concerns about child abuse in the 1940s, 1950s, and 1960s.

\section{Britain}

Initial discussions around the battered child syndrome in America were the product of interactions between a maturing technology, the $\mathrm{x}$-ray; a small professional community working primarily in radiology and paediatrics, supported by laboratory staff; and the explanations provided by parents and children themselves in daily interactions with clinicians. Through the published work in this field, as well as meetings at conferences, discussions around the syndrome were published in Britain during the mid-1960s, not long after the release of Kempe's initial article. Notably, in 1963, the orthopaedic surgeons D. Li Griffiths and F. J. Moynihan published an article in the British Medical Journal looking 'to give publicity to a syndrome which we think commoner than is usually believed'. ${ }^{14}$ The article's characterisation of the syndrome was broadly in line with Kempe's original description, and offered three further case studies. Again, images from the x-ray were significant, with one showing healing fractures in seven ribs of a two-month-old baby, only made visible through this technology. Testifying to the challenges facing such work, Griffiths and Moynihan wrote that many doctors were 'reluctant to believe that such assaults on innocent babies are possible'. ${ }^{15}$ Nonetheless, others wrote supportively to the British Medical Journal, suggesting that these cases may only be the 'tip of the iceberg', and lobbying for further research. ${ }^{16}$

The problem of battered children was conceptualised as a transnational or 'universal' one from its inception, and later consciously so at the International Congress on Child Abuse, held in Geneva in 1976. ${ }^{17}$ Significantly, medical, social work, and charitable communities in Britain and America exchanged and co-constructed knowledge about this syndrome. Following a meeting with Kempe in Colorado in 1964, the Director of the NSPCC Arthur Morton became 'very keen that the society should be in the forefront of the work needed to counter what became known 
as the "battered baby syndrome". ${ }^{18}$ Under Morton's guidance, the NSPCC founded the Battered Child Research Unit in 1966, aiming to 'create an informed body of opinion about the syndrome and to devise methods of treatment'. ${ }^{19}$ Evidencing the significance of transatlantic relationships in this moment, the unit was established at 'Denver House' in tribute to Kempe's work in Denver, Colorado. ${ }^{20}$

While the NSPCC and British medical profession were initially 'conduits', 'exporting' American knowledge about the battered child syndrome, they came to be significant in constructing such knowledge also, as part of a broader transnational network united through, for example, work in the international journal Child Abuse \& Neglect. ${ }^{21}$ Morton and Kempe each spent time working within both America and Britain, and Steele - another author of the initial 'Battered Child' journal article-also held many discussions with the NSPCC. ${ }^{22}$ These networks, then, evidence a transition of ideas between transatlantic medical communities, but also between medical and charitable ones.

While medical and charitable communities in Britain and America were discussing the 'battered child syndrome' by the mid-1960s, there was no singular definition of this term. Definitions were more clearly divided across professional lines than national ones. Broadly, clinicians agreed that the syndrome was a collection of symptoms and signs primarily apparent in young children under the age of three who were subjected to violence, usually at the hands of their parents. ${ }^{23}$ Within this vague definition however, numerous medical specialists from various fields asserted the unique role of their own professions in providing the definitive characterisation. Radiologists argued that the battered child syndrome had distinct features which only x-rays could reveal. ${ }^{24}$ M. J. Gilkes of the Sussex Eye Hospital highlighted the ocular conditions connected with the syndrome, claiming that in cases where the battered child was being diagnosed, specific appearances, visible only to trained ophthalmologists, would 'considerably increase one's suspicions'. ${ }^{25}$ Suzanne Alexander, from the Institute of Dermatology in London, and surgeon A. P. Barabas likewise both emphasised their own professions' roles in differentiating between purposefully inflicted bruises and infants particularly prone to bruising due to the existence of an underlying condition (such as the Ehlers-Danlos syndrome). ${ }^{26}$ Psychiatrists also became significant in the popular coverage of the battered child, and contemporary tabloid analysis speculated that psychiatrists may be able to undertake 'extensive brain checks' and to identify 'brain abnormalities' in violent parents. ${ }^{27}$ 
The initial development of the battered child syndrome was then not merely the emergence of child abuse as a 'medical problem', but rather was shaped by debates between several medical specialities, many of which, not least radiology, were becoming increasingly expensive in the 1960s due to the development of new technologies. ${ }^{28}$ Early medical works on this topic included a clear focus on the character of violent parents, though in terms of understanding how best to identify such adults, rather than in thinking about how to treat them. Medical communities in Britain began to focus on this issue very quickly after those in America, in part because of the ease of transferring knowledge through international medical journals, but also reflective of the relatively small groups of researchers initially interested in this debate. Similar definitions emerged in Britain and America although, in subsequent years, Parliamentarians would suggest that the differences between the American health system and the National Health Service in Britain had shaped a different 'contractual relationship' between patient and doctor, and thus a separate model of moral duty around the battered child. ${ }^{29}$ While the syndrome was said to potentially affect children of 'any age', a clear model of childhood vulnerability emerged, with a small group of researchers key in representing the interests of the helpless infant.

\section{Recovering the Child ${ }^{30}$}

Concerns about children's experiences and feelings were not absent from early medical discussions, though the characterisation of the battered child syndrome tended against consideration of children's own viewpoints in three key ways. First, the syndrome was typically restricted to apply to children under the age of three, in part given a hope that older children would be capable of themselves giving a reliable patient history. ${ }^{31}$ Second, since this syndrome was initially characterised by radiologists, the diagnostic material used was an x-ray image: a monotone photograph which saw the inside of, and yet in a sense removed what was human from, its subject. With this diagnostic aid, the testimony of the interpreting physician was crucial, but accounts from the young children themselves were less necessary. Third, the construction of violence against children as a 'syndrome' put this issue firmly in the medical arena, as the responsibility of expert paediatricians to understand and manage.

At the same time, concerns about the child's social and emotional positions were never absent from early discussions of the syndrome. Notably, in defining the syndrome, clinicians recognised that a variety of forms of 
abuse often accompanied one another-that the physical abuse of the battered child would often be accompanied by emotional abuse and neglect, which must also be prevented and stopped. ${ }^{32}$ Building on this recognition of the multivariate nature of many child protection cases, paediatricians, radiologists, and other clinicians recognised that they needed to work closely with a range of social agencies. Kempe's co-edited collection The Battered Child (1968) featured chapters written by a social worker, a welfare department worker, a lawyer, and a policeman, situated alongside those by a radiologist, a paediatrician, and a psychiatrist. The text explicitly highlighted the contributions made by 'many disciplines involved in helping the battered child and his parents'. ${ }^{33}$ The battered child syndrome was thus not to be managed by clinicians alone, but rather by a range of social and clinical professionals. Such collaborative efforts were made even as social medicine itself shifted its focus towards individual responsibility and lifestyle issues. ${ }^{34}$

Focus was also moved from outside of professional spaces into community ones, with, for example, one letter to the British Medical Journal in 1964 calling for a shift in community attitudes whereby violence was no longer overlooked..$^{35}$ In making this type of case, clinicians acknowledged the limitations of their disciplines in child protection though, at the same time, the specific nature of these 'communities' was rarely addressed in medical publications. Challenging purely clinical explanations of the syndrome further, Caffey recognised that while radiologic signs may tell the radiologist with 'full confidence' that the child had 'suffered from mechanical injury', these visuals alone could not determine who had hurt a child. ${ }^{36}$ These kinds of clinical arguments to an extent reflected a level of self-awareness from medical professionals concerned for child welfare, who were thinking about the social and emotional contexts of childhood and seeking inter-professional collaboration. However, the sense of concern about clinical accuracy also cannot be removed from a context in which, in the 1950s, 1960s, and 1970s, medical authority was encountering new challenges from malpractice suits, newspaper sensationalism, and an increased proliferation of alternative providers. ${ }^{37}$

Nonetheless, discussions of the battered child syndrome broke down certain clinical boundaries. Notably, radiologists, paediatricians, and other clinicians described these cases in highly emotional terms, again demonstrating a level of attentiveness to the interior lives of children and infants. Discussions in the British Medical Journal referred to 'our most helpless patients', and the 'evil' and 'distinctive nightmare quality' of battered 
child cases. ${ }^{38}$ Expressing further concern about the inner lives of the child, Caffey, addressing the American Pediatric Society in 1965, emphasised how many of his 'thousands of small patients' were 'exhausted by disease and frightened by the seeming horrors of radiographic examination'. ${ }^{39}$ When narrating their own responses to these cases, and in professional discussion, clinicians thus near immediately felt compelled to discuss their own emotions as well as their professional credentials.

As a letter from Kempe to a friend, later published by his daughter, claimed, he was in part driven to his work by an academic agenda of 'intellectual honesty' and 'rage' at the misplaced diagnoses children were given. He was also however, he stated, motivated by concern for the abused child, his siblings, and his parents. ${ }^{40}$ Such evocative uses of language, and expressions of emotion as motivators for research, were not common in contemporary medical journals. ${ }^{41}$ Not only did these statements break down cultural tropes of detached clinical authority, they also demonstrated that the re-emergent anxieties about child abuse in the mid-twentieth century would be embedded, even from an early stage, with concerns about the emotions and experiences of children and professionals. The expectation that clinicians, social workers, and policy-makers would also discuss their family lives, and that they would perform experiential and emotional expertise, developed significantly in later decades, as this book will trace.

Anticipating later tensions in these debates, one piece in the British Medical Journal in 1964 stated that the 'emotions aroused by these cases' may incite the 'quixotic desire for retribution' and a 'fervour to protect possibly innocent relatives'. ${ }^{42}$ Indeed, while interest in thinking about the social and emotional connotations of child protection developed from the 1960s, medical communities in Britain and America also rejected the idea of parental violence. Touring America, giving speeches about this syndrome in hospitals and universities, Kempe's wife Ruth, herself a significant paediatrician who co-authored his later work, received mixed responses. She later reported that while half of those she met responded with, 'Thank you so much for confirming what I've suspected, and for educating us', the other half argued, 'I don't know where you get your information, I've been in practice for years and have never seen any evidence of child abuse. ${ }^{43}$ In the British context, likewise, an editorial in the British Medical Journal recognised that 'medical men' were 'naturally unwilling to become involved in criminal proceedings', but argued nonetheless that it was 'clearly' their 'duty'. ${ }^{44}$ This careful framing suggested 
an ongoing expectation of professional resistance, and an early moment in which ideas about child protection were being tied to theories of duty, responsibility, and morality. Interest in children's emotional and social lives underlay early understandings of the battered child syndrome, but these interests were not universally accepted.

\section{Studying the Parent}

In the initial medical descriptions of the battered child, parents tended to be a side feature. Kempe's initial 'Battered Child' article acknowledged that there was 'meager' research around the parents of battered children, despite the fact that they were the primary perpetrators of violence. ${ }^{45}$ From the time that this article was published in 1962, however, numerous social and psychological surveys emerged in Britain seeking to further understand violent parents. One of the earlier studies in this area was by the NSPCC's Battered Child Research Unit and was entitled, 78 Battered Children. Published in September 1969, the study was co-authored by Angela E. Skinner, an associate at the Institute of Medical Social Work, and Raymond Castle, a social worker. The research assessed 45 battered boys and 33 battered girls aiming to establish the demographics and social and psychological characteristics of the families involved. ${ }^{46}$ Skinner and Castle compiled their sample retrospectively, by asking all NSPCCemployed social workers to provide their case records about under-fours who had warranted medical attention due to physical injury between July 1967 and June 1968. ${ }^{47}$ Of the parents who had hurt their children, the report identified 33 were male, 42 female, and 3 acting in collaboration. Battering parents in the sample were often relatively young, with the mean age of 22-25. The study argued that battering had a strong correlation with 'character disorders', with parents either 'habitually aggressive' or suffering from 'impoverished personalities' that left them unable to 'sustain nurturing relationships'. ${ }^{48}$ Notably, in this work the violent parent shifted from a side-consideration of medical studies, focused on 'objective' signs such as $\mathrm{x}$-ray imagery, to the centre of psychological and social examination.

Interest in the psychological and social contexts of violent parents continued apace in the late 1960s and the 1970s, led by the NSPCC and also by independent psychiatrists. Two separate key themes emerged in this research-tensions about whether such parents were part of a 'social problem group' and, relatedly, about whether the parents had themselves been 
subject to violence in childhood. In terms of the first theme, numerous psychological studies emphasised that violent parents did not typically belong in any one demographic group, and that nor were they defined by social class, ethnicity, gender, or education. ${ }^{49}$ At the same time, clinical and media discussions of these parents echoed historic discussions of 'social problem groups' or 'problem families' which have reappeared in various forms since at least the Victorian period. ${ }^{50}$ Indeed, letters to the British Medical Journal in 1966 and 1967 explicitly characterised battering parents within a 'large group of social problem families', and as often 'already known to their general practitioners, health visitors, and various social agencies as having many problems'.$^{51}$

This representation-of families afflicted by low levels of personal responsibility, poor social environments, and inadequate skills of home management-was taken up enthusiastically by tabloid press discussing battered children. In April 1965, the Daily Mail discussed battered babies as a 'major social disease'; making clear the competing visions of child protection as a social and a medical problem in this moment. ${ }^{52}$ The article quoted an unnamed 'London psychiatrist', who reportedly told the paper that battering parents were not drawn predominantly from 'the lower-paid section of the community, nor are they unintelligent' ${ }^{53}$ Further, the article asserted, such parents may be 'well-dressed', with a baby who appears 'healthy, despite his bruised face and limbs'. ${ }^{54}$ Nonetheless, and in highly coded language, the article also quoted the psychiatrist's statement that battering families were those 'living in isolation, without friends, without grandparents to help care for children, with economic difficulties, who are overworked and overtired'. ${ }^{55}$ While overtly denying that they perceived a class basis in battered child-cases, tabloid press and clinicians alike were explicitly-and not subtly_placing their discussions within a significant historical trajectory of stigmatising and paternalist debate.

The second key theme in early research about battering parents was an assumption that they had been subjected to violence themselves during their own childhoods. This assumption emerged from the very inception of discussions about the battered child syndrome: Kempe's original article emphasised that there was 'some suggestion that the attacking parent was subjected to similar abuse', and that this may be 'one of the most important factors' in these cases. ${ }^{56}$ The NSPCC, likewise important in early debates about the syndrome, confidently stated in a review article that there was 'general agreement' in relevant literature that violent parents 'were themselves the victims of physical/emotional abuse or neglect' ${ }^{57}$ 
This idea of violence as cyclical extended beyond these intense research communities alone. In Parliament in 1969, Labour Member Joan Lestor, a former nursery school teacher, argued that there was 'one single matter' through the battered child cases - that the parents involved may have had 'grossly unhappy and grossly deprived childhood[s]'. ${ }^{58}$ In the same year, Home Secretary James Callaghan expressed an aim to 'prevent the deprived and delinquent children of today from becoming the deprived, inadequate, unstable, or criminal citizens of tomorrow' ${ }^{59}$ As was suggested by Lestor's language of unhappiness, thinking about cycles of violence was sometimes used sympathetically, looking to explain the inexplicable behaviours of parents. In one of Kempe's case studies, for example, he explained that a mother repeated a pattern of violence from her own childhood, despite her 'very strong conscious wishes to be a kind, good mother' ${ }^{60}$ Discussing the battered child further, paediatricians and representatives of the UK Home Office argued in the late 1960s that best interests of the child and the rehabilitation of parents were 'not contradictory aims' but rather 'joint ones'. These spokespeople argued that the majority of parents could stop injuring their children, with professional intervention, and that many parents felt 'exasperated' by their children's behaviours at certain times. ${ }^{61}$

While offering a sympathetic approach to parents, therefore, discussions about the battered child did not lead to debate about how best to support all survivors of abuse. Early discussions about the battered child syndrome contained threads of interest in parental experience, but these were analysed through the interlinked lenses of social problem groups and cyclical violence, and used to justify paternalist professional intervention. Psychological, political, and charitable interest turned quickly to the inner lives of parents involved in child protection cases; however, parents were unable to guide such debate. These clinical and political visions of parenting emerged as part of a broader focus on preventative casework and family maintenance in the 1950s and 1960s. ${ }^{62}$ While children, parents, and survivors did not actively influence mid-twentieth-century discussions, these discussions did contain early interest in the experiences and emotions of families. This interest became significant over the late 1960s, 1970s, and particularly in the 1980s, as the rest of this book demonstrates. Indeed, this initial construction of child protection was quickly challenged, broadened, and, to an extent, overturned. Notably, the next two chapters trace rising concerns about children's experiences and emotions. In these debates, the initial sympathetic approach to parents and to family maintenance became controversial. 


\section{CONCLUSION}

Drawing on research from the 1940s and 1950s, from the early 1960s a shift occurred in British society within which academic, medical, charitable, and social work communities increasingly discussed the mistreatment of children in published works. While a shift took place over these years, the pace of change should not be overstated. By 1970, many practising medics and social workers continued to deny or ignore the existence of parental violence. Writing for the British Medical Journal in 1970, the paediatrician Bruno Gans described the case of a five-monthold infant repeatedly admitted into a southeast London Hospital with injuries in his hand. Despite $\mathrm{x}$-ray evidence that a needle had been embedded in the child's heel, and the fact that the child's sibling had recently died in another hospital, Gans reported that his suggestions that this child may manifest the battered child syndrome were met with horror. When suggesting the diagnosis to his ward sister, Gans wrote, 'she was appalled at my even thinking of such a possibility'. ${ }^{63}$ In 1969 , relatedly, the NSPCC's 78 Battered Children survey emphasised that social workers and clinicians alike struggled to believe that parents could or would hurt their children. ${ }^{64}$ The report also emphasised that some social workers pushed parents towards alternative explanations of childhood injury. In one reported case, a social worker suggested 'all kinds of accidents' may have caused a child's injuries and 'even suggested the dog', but the parent 'would have none' ${ }^{65}$

Thus, a change took place in the mid-twentieth century in terms of medical and social work discussions of abuse, and yet this was not instantaneous nor was it entirely 'new'. Nonetheless, some attitudinal shifts did take place, often motivated by research. In the early 1960s, the paper by Kempe, Silver, Steele, Drogemueller, and Silverman was highly significant. In later years, Kempe was nominated for Nobel Peace Prize for his contribution to children's safety, and the American Medical Association recognised this paper as one of the sixty most important published medical manuscripts of the twentieth century. ${ }^{66}$ From the late 1960s, the NSPCC's Battered Child Research Unit became significant in conducting research around the syndrome, and seeking to characterise and understand families. Work exchanged amongst transnational communities of radiologists, paediatricians, social workers, and charities in Britain and North America thus 
sought to direct further resources to the study of battered children which, from early discussions, became conversations about physical, emotional, and neglectful forms of maltreatment more broadly.

The growing awareness of child abuse in this period was complex. There was no simple shift in the management of violent families from public health doctors to social workers, or from the medical to the social. ${ }^{67}$ Rather, medical concerns about child protection were always inflected by social anxieties, developed alongside the strengthening of social medicine in the 1940s and 1950s, and shaped by clinical collaboration with social work agencies. Paediatric radiologists and other clinicians expressed their concerns about abuse in emotional language. Collaboration between social and medical actors did not yet extend to including children, parents, or survivors in debate. Indeed, much research was framed in paternalist and stigmatising terms, and research was often driven by a primary fixation on family maintenance. Nonetheless, these shifts in thinking about the inner lives of children and parents did, at the same time, set the stage for the developing significance of experiential and emotional expertise.

\section{Notes}

1. Parts of the following section were first explored and used in my article, Jennifer Crane, "'The Bones Tell a Story the Child Is Too Young or Too Frightened to Tell": The Battered Child Syndrome in Britain and America', Social History of Medicine, 28 no. 4 (2015): 767-788. Select points and ideas are reused here in line with the article's open access status, as it was published under a Creative Commons CC-BY license.

2. Nigel Parton, 'A Natural History of Child Abuse: A Study in Social Problem Definition', British Journal of Social Work, 9 (1979), 436; Harry Ferguson, Protecting Children in Time: Child Abuse, Child Protection and the Consequences of Modernity (Basingstoke: Palgrave Macmillan, 2004), 4, 80, 89, 104, 108-109; Harry Hendrick, Child Welfare: Historical Dimensions, Contemporary Debate (Bristol: The Policy Press, 2003), 161163; Harry Hendrick, Child Welfare: England 1872-1989 (London: Routledge, 1994), 225.

3. See Crane, "The bones tell a story the child is too young or too frightened to tell": $767-788$.

4. For personal recollections on the early development of $\mathrm{x}$-ray departments in various regions see: Henry Crooks, 'A Life History with X-Rays', The Invisible Light: The Radiology History and Heritage Charitable Trust, 13 
(May 2000): 11-38, the Chesney Twins, 'We Remember...', The Invisible Light: The Radiology History and Heritage Charitable Trust, 16 (2001): 6-13, Mavis V. Reynolds, '50 Years on-What it was like to be a radiography student in 1946', The Invisible Light: The Radiology History and Heritage Charitable Trust, 17 (2002): 8-10, Rita Mason, 'A Family Affair', The Invisible Light: The Radiology History and Heritage Charitable Trust, 18 (2002): 16-27. Adrian M. K. Thomas, 'The development of radiology from the discovery of x-rays in 1895', The Invisible Light: The Journal of the British Society for the History of Radiology, 23 (November 2005): 14.

5. Reprinted in: John Caffey, 'The Classic: Multiple Fractures in the Long Bones of Infants Suffering from Chronic Subdural Haematoma', Clinical Orthopaedics and Related Research, 469 (2011): 757.

6. Fred Silverman, 'The Roentgen Manifestations of Unrecognised Skeletal Trauma in Infants', American Journal of Roentgenology, 69 (1953): 424.

7. Paul V. Woolley and William A. Evans, 'Significance of Skeletal Lesions in Infants Resembling those of Traumatic Origin', Journal of the American Medical Association, 158 (1955): 541.

8. C. H. Kempe, Frederic N. Silverman, Brandt F. Steele, William Droegemuller, Henry K. Silver, 'The Battered Child Syndrome', Child Abuse and Neglect, 9 (1985): 143, originally published in Journal of the American Medical Association, 181 (1962): 17-24.

9. Kempe et al., 'The Battered Child Syndrome', pp. 143-154; Annie Kempe, A Good Knight for Children: C. Henry Kempe's Quest to Protect the Abused Child (e-book, 2007), 69\%.

10. Kempe et al., 'The Battered Child Syndrome': 143-144.

11. Ibid., 143.

12. Ibid., 144.

13. John Caffey, 'Significance of the history in the diagnosis of traumatic injury to children', The Journal of Pediatrics, 67, no. 5 (1965): 1009.

14. D. Li. Griffiths and F. J. Moynihan, 'Multiple Epiphysial Injuries in Babies ('Battered Baby' Syndrome)', British Medical Journal, 21 December 1963: $1558-1561$.

15. Ibid., 1558-1561.

16. Anthony Vickers, 'Battered Babies', British Medical Journal, 4th January 1964, 60, Arthur Morton, 'Battered Baby' Syndrome', British Medical Journal, 18 January 1964, 178.

17. Pierre E. Ferrier, 'Foreword-Proceedings of the 1976 International Congress on Child Abuse and Neglect-Geneva, W. H.O.-September 20-22', Child Abuse \& Neglect, 1 (1977), iv.

18. John Low, 'Obituary: The Reverend Arthur Morton', The Independent, 4th April 1996, available online at <http://www.independent.co.uk/ news/people/obituary--the-rev-arthur-morton-1303186.html>. 
19. Edwina Baher, Clare Hyman, Carolyn Jones, Ronald Jones, Anna Kerr, Ruth Mitchell, At Risk: An Account of the Work of the Battered Child Research Department, NSPCC (London and Boston: Routledge \& Kegan Paul, 1976), vii; Arthur Morton, 'Foreword', in Angela Skinner and Raymond Castle (eds) 78 Battered Children: A Retrospective Study (Hoddesdon: Thomas Knight and Co, 1969).

20. Phillip Jenkins, Intimate Enemies: Moral Panics in Contemporary Great Britain, (New York: Aldine de Gruyter, 1992): 104; Parton, 'A Natural History of Child Abuse': 439.

21. Jenkins, Intimate Enemies, 104, Hacking, The Social Construction of What? (Cambridge, MA: Harvard University Press, 1999), 148.

22. Betty Jerman, 'You seen a clean pinny. The bruises are underneath', The Times, 8 January 1967, 10; Low, 'Obituary: The Reverend Arthur Morton'; Arthur Morton, 'Introduction', Skinner and Castle, 78 Battered Children.

23. Memorandum of the British Paediatric Association Special Standing Committee on Accidents in Childhood, 'The Battered Baby', British Medical Journal, 1 (1966): 601, as cited in Arthur F. Hughes, 'The Battered Baby Syndrome-a Multi-disciplinary Problem', Case Conference, 14, no. 8 (December 1967): 305.

24. See for example Bruno Gans, 'Unnecessary X-Rays?', British Medical Journal, 28 February 1970: 564; John Caffey, 'Significance of the history in the diagnosis of traumatic injury to children', The Journal of Pediatrics, 67 , no. 5 (1965): 1012.

25. M. J. Gilkes and Trevor P. Mann, 'Fundi of Battered Babies', The Lancet, 26 August 1967: 468-469.

26. Suzanne Alexander, “"Battered Baby” Syndrome', British Medical Journal, 9 May 1964: 1255; A. P. Barabas, 'Battered Baby or Ehlers-Danlos Syndrome?', The Lancet, 4 March 1967: 511.

27. Keith Colling, 'Battered babies "face new dangers", Daily Mail, 2 April 1973: 11.

28. Adrian M. K. Thomas and Arpan K. Banejee, The History of Radiology (Oxford, e-book, 2013), 78\%.

29. Hansard, House of Commons, Fifth Series, 25 July 1969, Vol. 787 cc. 2315.

30. Parts of the following section were first explored and used in my article, Crane, "The bones tell a story the child is too young or too frightened to tell": 767-788. Select quotes and ideas are reused here in line with the article's open access status, as it was published under a Creative Commons CC-BY license. 
31. Caffey, 'Significance of the history': 1013; Hughes, 'The Battered Baby Syndrome': 305.

32. This was particularly recognised from the later 1970s, see: Ruth S. Kempe and C. Henry Kempe, Child Abuse (Cambridge, Massachusetts: Harvard University Press, 1978), 12-13.

33. Ray E. Helfer and C. Henry Kempe, 'Introduction', in Ray E. Helfer and C. Henry Kempe (eds) The Battered Child (Chicago: University of Chicago Press, 1968).

34. Shaun Murphy, 'The Early Days of the MRC Social Medicine Research Unit', Social History of Medicine, 12, no. 3 (1999): 389-406.

35. Eric Turner, "'Battered Baby" Syndrome', British Medical Journal, I February 1964: 308.

36. Caffey, 'Significance of the history': 1012.

37. Edward Shorter, 'The History of the Doctor-Patient Relationship', in W. F. Bynum and Roy Porter, eds, Companion Encyclopedia of the History of Medicine, volume 2 (New York, London: Routledge, 2001), 794-795; Allan M. Brandt and Martha Gardner, 'The Golden Age of Medicine?', in Roger Cooter and John Pickstone, eds, Companion to Medicine in the Twentieth Century (London: Routledge, 2003), 21-38. Mike Saks explores the rise of a 'counter culture' against 'orthodox medicine', symbolised by trends in litigation and self-help, and rising public interest in alternative medicine and holistic health care in 'Medicine and the Counter Culture', in Cooter and Pickstone, Companion to Medicine in the Twentieth Century, $113-123$.

38. Griffiths and Moynihan, 'Multiple Epiphysial Injuries in Babies': 15581561; 'Cruelty to Children', British Medical Journal, 21 December 1963: 1544; E. E. Sumpter, 'Battered Baby Syndrome', British Medical Journal, 26 March 1966: 800-801.

39. Caffey, 'Significance of the history': 1009.

40. As quoted in Kempe, A Good Knight for Children, 66-67\%.

41. This assumption-about the absence of emotion in contemporary medical publications-will be tested and challenged by the work of the Wellcome Trust Senior Investigator Award on 'Surgery and Emotion', led by Dr Michael Brown at the University of Roehampton. This research group provides regular updates on their work through their website, http://www. surgeryandemotion.com/.

42. Eric Turner, “Battered Baby” Syndrome', British Medical Journal, I February 1964: 308.

43. Kempe, A Good Knight for Children, 71\%.

44. 'Cruelty to Children', p. 1544.

45. Kempe et al., 'The Battered Child', 145.

46. Skinner and Castle, 78 Battered Children, 1.

47. Ibid., 4. 
48. Ibid., 15-16, 20.

49. B. F. Steele and C. B. Pollock, 'A psychiatric study of parents who abuse infants and small children', P. F. Helfer and C. H. Kempe (eds), The Battered Child; C. H. Kempe, 'The battered child and the hospital', Hospital Practice, 4 (1969): 44-57 as cited in Selwyn M. Smith, 'The Battered Child Syndrome-Some Research Aspects', The Bulletin of the American Academy of Psychiatry and the Law, 4, no. 3 (1976): 235.

50. See: John Welshman, Underclass: a history of the excluded since 1880 (2nd edition, London: Bloomsbury, 2013); John Welshman, 'Troubles and the family: changes and continuities since 1943', Social Policy and Society, 16 (1) (2017): 109-117; John Welshman, From Transmitted Deprivation to Social Exclusion: Policy, Poverty, and Parenting (Bristol: Policy Press, 2007); Michael Lambert, "Problem families" and the post-war welfare state in the North West of England, 1943-74 (PhD thesis, Lancaster University, 2017).

51. Simon Yudkin, 'Battered Baby Syndrome', British Medical Journal, 16 April 1966, 980; G. M. Fleming, 'Cruelty to Children', British Medical Journal, 13 May 1967, 422.

52. Hugh McLeave, 'What makes these parents so cruel', Daily Mail, 22 April $1965,10$.

53. Ibid., 10 .

54. Ibid., 10.

55. Ibid., 10.

56. Kempe et al., 'The Battered Child Syndrome', 145.

57. Baher et al., At Risk, 65.

58. Hansard, House of Commons, fifth series, 25 July 1969, vol. 787, col. 2309.

59. Callaghan quote: Hansard, House of Commons, fifth series, 11 March 1969 , vol. 779, col. 1176.

60. Kempe et al., The Battered Child Syndrome', 145.

61. Simon Yudkin, 'Battered Baby Syndrome', British Medical Journal, 16 April 1966, 981; G. M. Fleming, 'Cruelty to Children', British Medical Journal, 13 May 1967, 422. See also: Kempe and Kempe, Child Abuse, 8, 10.

62. Call for a sympathetic approach in: Skinner and Castle, 78 Battered Children, 20. An emphasis on prevention is clear within the Annual Reports of Barnardos and the Children's Society: Liverpool University Special Collections and Archives, Barnardos Archives, D239 A3/1/98, Annual Report 1963, 12; Children's Society Archives, Annual Reports, AR85.0063.44 Annual Report for 1966, 4; Children's Society Archives, Annual Reports, AR85.0063.454, Annual Report for 1967, 3. For discussion of social policy of this period which focused on prevention and family maintenance see: Harry Hendrick, Children, Childhood and English Society 1880-1990 (Cambridge: Cambridge University Press, 1997), 56-57. 
63. Gans, 'Battered Babies', 1286-1287.

64. Skinner and Castle, 78 Battered Children, 7.

65. Ibid., 19.

66. Kempe, A Good Knight for Children, $71 \%$.

67. See discussion of this shift, and of when exactly it occurred, in: Pat Starkey, 'The Medical Officer, the Social Worker, and the Problem Family, 1943 to 1968: The Case of Family Service Units', Social History of Medicine, 11, no. 3 (1998): 421-441.

Open Access This chapter is licensed under the terms of the Creative Commons Attribution 4.0 International License (http://creativecommons.org/licenses/ by $/ 4.0 /$ ), which permits use, sharing, adaptation, distribution and reproduction in any medium or format, as long as you give appropriate credit to the original author(s) and the source, provide a link to the Creative Commons license and indicate if changes were made.

The images or other third party material in this chapter are included in the chapter's Creative Commons license, unless indicated otherwise in a credit line to the material. If material is not included in the chapter's Creative Commons license and your intended use is not permitted by statutory regulation or exceeds the permitted use, you will need to obtain permission directly from the copyright holder.

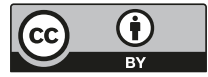

